\section{The first "Award to Active Cities Contest" for the Region of the Americas}

\author{
Andrea B. Neiman ${ }^{1}$ \\ and Enrique R. Jacoby ${ }^{2}$
}

Physical activity is no longer seen as merely a recreational pastime but is recognized as a basic pillar of our present and future health. More and more, however, a healthy lifestyle that includes regular physical activity has become an issue of politics and policy and not solely individual volition $(1,2)$.

City officials throughout the Region of the Americas have increasing influence over areas critical to active living such as transportation, urban design, recreation, and crime control. Indeed, access to public spaces for safe recreation, alternative modes of transportation, and community design are all crucial factors that are consistently associated with promoting a physically active lifestyle $(3,4)$. Sustainable, pedestrian-friendly planning has gone on for many years in such cities as Curitiba, Brazil; Bogotá, Colombia; and Quito, Ecuador. These cities demonstrate the positive effects of thoughtful community design, having transformed public spaces into safer, better places for walking, social encounters, recreation, and other activities of daily living (5-7).

\section{HONORING EFFORTS IN THE AMERICAS TO CREATE PUBLIC SPACES FOR RECREATION AND ACTIVE LIVING}

To recognize the efforts of municipal leaders in creating and maintaining public spaces for safe recreation and active living, the Centers for Disease Control and Prevention (CDC) of the United States of America and the Pan American Health Organization (PAHO) cosponsored the first "Award to Active Cities Contest," which was part of the World Health Day 2002 "Move for Health" celebration. The contest, limited to cities in the Region of the Americas with no more than 1000000 inhabitants, drew over 140 completed applications, 95\% of which were from Latin America.

For the competition a 25-item application form was developed and disseminated in both English and Spanish to all the PAHO country offices, to ministries of health, and to other organizations concerned with physical activity. The application form was also available on the Internet. The information from the completed application forms was entered into a computer database software program, with all the variables coded and assigned a numeric value. Based on their point scores, the applications underwent a preliminary quantitative and qualita- 
tive review. The final winners were chosen by an expert selection committee.

The applicants were considered in two regional categories: (1) Latin America and the Caribbean and (2) Canada and the United States. The winners were recognized in a special ceremony held at the Health Promotion Forum in the Americas in Santiago, Chile, in October 2002. From the applicants from Latin America and the Caribbean, the first-place award went to Loja, Ecuador; second place went to Santiago de Surco, Peru; and third place to Balcarce, Argentina. Only seven entries were received from cities in Canada or the United States, so only one award in that category was granted; it went to Surrey, British Columbia, Canada. In addition, there were four honorable mention awards granted: Eugene, Oregon, United States; La Habana Vieja, Havana, Cuba; Lo Barnechea, Santiago, Chile; and Manizales, Caldas, Colombia.

The enthusiastic response to this initiative and the encouraging progress seen in many cities throughout Latin America also brought to light some of the difficult challenges municipal leaders face as their cities rapidly grow, develop, and industrialize (7). Some types of built environments force residents to rely on motorized transportation in place of common means of conveyance such as walking and cycling. This increases traffic congestion and air pollution while reducing open, public green space available for safe recreation and social interaction (8). Further, such trends may be contributing to the rising levels of sedentary living in the Americas (9). It is estimated that about two of every three adults living in an urban area in the Region of the Americas lead a sedentary lifestyle, meaning that they are simply not active enough to accrue health benefits (10). This is cause for concern because, as recent epidemiologic evidence unequivocally shows, independent of other risk factors such as tobacco, alcohol, and poor diet, physical inactivity is associated with noncommunicable diseases (NCDs) such as stroke, cardiovascular disease, diabetes, and osteoporosis as well as their risk factors such as high blood pressure, high cholesterol, and obesity (11) These NCDs were once thought to be only "diseases of affluence," but they are now the leading causes of morbidity and mortality throughout the Region of the Americas, accounting for some $70 \%$ of all-cause mortality and $66 \%$ of the burden of disability-adjusted life years (DALYs) and afflicting persons of all ages and backgrounds. ${ }^{3}$ In economic

\footnotetext{
Pratt M, Jacoby ER, Neiman AB. The challenges of promoting physical activity in the Americas. Working Paper to the WHO/PAHO Regional Consultation of Diet, Physical Activity and Health. San José, Costa Rica, April 2003.
}

terms, it has been estimated that in the United States of America US\$ 24 billion to US\$ 75 billion, or $2 \%$ to $7 \%$ of the total health care costs, are attributable to physical inactivity alone $(12,13)$. Indeed, the experience in the United States suggests that similar economic burdens can be expected in the future in all the countries of the Americas.

The impact of the built environment on levels of physical activity is of growing importance, particularly in Latin America, as cities are home to more than two thirds of the population and concentrate great economic and political power. Indeed, the health and quality of cities will determine the future health and quality of life for most persons in the Region of the Americas (7).

Fortunately, activities such as cycling and walking, which can be a part of everyday life, offer a promising means of improving population levels of physical activity and health. That is because those everyday activities are relatively easy for the vast majority of the population to perform, they are low in cost, and they offer relatively little risk of injury (14). Additionally, an active lifestyle that emphasizes moderate-intensity activities, such as walking and cycling on most days of the week, is as effective in providing health benefits as moreintense, traditional, structured activities such as aerobics and sports $(15,16)$. Increased use of nonmotorized transportation, such as cycling and walking, in combination with access to public transportation, has been shown to positively affect a number of issues that continue to challenge many burgeoning and established cities throughout the Region. These issues include traffic congestion, air pollution, sustainable land-use development, social capital, and marginalization of lower-income residents (17).

\section{INNOVATIVE SOLUTIONS THAT PROMOTE HEALTHY LIVING}

The strong response to the Award to Active Cities Contest demonstrates that city officials throughout Latin America recognize the essential link between the environment-including issues of safety, access to public areas for recreation, traffic congestion, and air quality - and healthy, active living. Loja, Ecuador, for example, introduced an important recycling initiative called the "Integrated Solid Waste Management Program," in which community members played a key role in establishing the city's first sanitary landfill. The city conducted an educational campaign and distributed colored recycle waste bins to households throughout the city. Now, homes representing nearly $90 \%$ of the city's population sort their recyclable wastes. 
To expand and preserve the many green areas in the city of Santiago de Surco, Peru, water purified from the Surco River runs through a highly efficient irrigation system called the Yacumóvil. This portable irrigation system has reduced by $50 \%$ the amount of water used previously with cisterns, thereby creating a sustainable system for the future maintenance and development of parks, gardens, and other pedestrian-friendly areas for recreation and other activities.

Balcarce, Argentina, has promoted active living with numerous cycling and walking trails that are easily accessible throughout the city. These efforts have also resulted in the preservation of open, green spaces and a decreased reliance on private cars and motorcycles.

These three winning cities were far from the exception among the Contest applicants in demonstrating innovative approaches to fostering safe, social environments in which people live, work and engage in recreation. For example, almost $75 \%$ of the applicants regularly close to motor vehicles specific areas of their cities one or two days a week so that those areas can be used for recreation. Over $90 \%$ of the cities reported having a plan to improve public spaces, including the creation and maintenance of parks, bike trails, and walking paths.

In summary, we found the first Award to Active Cities Contest to be a true success. In addition to spurring strong interest and participation from local governments the Contest provided persons from a variety of disciplines, organizations, sectors, and perspectives a unique opportunity to understand the impact of their synergistic efforts in promoting physical activity and a healthy urban environment. City officials in the Americas are clearly in a position to positively influence the health and quality of life of millions of people. It is essential, therefore, that these leaders be recognized for and supported in their efforts to protect and improve individual and communal well-being. The Contest has provided leaders with the opportunity to convert individual experience into collective learning, thus helping to make the choice to be physically active the easiest choice and helping ensure a healthier future for all persons in the Region of the Americas.

\section{SINOPSIS}

\section{Primer "Concurso de Ciudades Activas" en la Región de las Américas}

Una vida sana, en la que se practica alguna actividad física con regularidad, se ha convertido en foco de atención politica $y$ en asunto de politicas, y ha dejado de ser solamente cuestión de voluntad personal. En la Región de las Américas esto cobra especial importancia en ambientes urbanos, donde viven más de dos terceras partes de la población. Los funcionarios públicos de las ciudades del continente americano están ejerciendo creciente influencia en ámbitos que guardan estrecha relación con una vida activa, tales como el transporte, el diseño urbano, el recreo y el control de la delincuencia. Para reconocer los esfuerzos de las autoridades municipales por crear y mantener espacios públicos conducentes a actividades de recreo en condiciones de seguridad $y$ a una vida activa, los Centros para el Control y la prevención de Enfermedades de los Estados Unidos de América y la Organización Panamericana de la Salud copatrocinaron el primer "Concurso de Ciudades Activas" para la Región de las Américas como parte de la celebración del Día Mundial de la Salud 2002, cuyo lema fue "Muévete, América!" En el concurso participaron solamente las ciudades con un máximo de 1000000 habitantes. Se recibieron más de 140 solicitudes, de las cuales 95\% provinieron de América Latina. Además de haber suscitado el interés y la participación de los gobiernos del nivel local, el concurso les dio a personas de distintas disciplinas, organizaciones, sectores y puntos de vista una oportunidad muy singular de comprender el alcance de sus iniciativas concertadas para promover la actividad física y ambientes urbanos sanos. El concurso también les brindó a las autoridades la posibilidad de convertir sus experiencias individuales en un aprendizaje colectivo, ayudándolas de esa manera a reparar en el hecho de que llevar una vida activa es el camino más fácil, y a lograr que todos los habitantes de la Región de las Américas gocen de buena salud en un futuro.

\section{REFERENCES}

1. Humpel N, Owen N, Leslie E. Environmental factors associated with adults' participation in physical activity: a review. Am J Prev Med 2002;22(3): 188199.

2. Frumkin $H$. Urban sprawl and public health. Public Health Rep 2002;117: 201-217.

3. Saelens B, Sallis J, Frank L. Environmental correlates of walking and cycling: findings from the transportation, urban design and planning literatures. Ann Behav Med 2003;25(2):80-91.

4. Bauman AE, Sallis JF, Dzewaltowski DA, Owen N. Toward a better understanding of the influences on physical activity: the role of determinants, correlates, causal variables, mediators, moderators, and confounders. Am J Prev Med 2002;23(2s):5-14.
5. Montezuma R. La transformación de Bogotá 1995-2000. Entre redefinición ciudadana y espacial. Santa Fe de Bogotá, Fundación Ciudad Humana 2002.

6. Evans G, Bohrer J. Urban parks \& green space in the design and planning of cities. In: Benson JF, Roe MH, eds. Urban lifestyles: spaces, places, people. Rotterdam: A.T. Balkema: 2000. Pp. 147154. 
7. Duhl LJ. An ecohistory of health: the role of 'Healthy Cities'. Am J Health Prom 1996;10(4):258-261.

8. Cervero R, Gorham R. Commuting in transit versus automobile neighborhoods. J Am Plan Assoc 1995;61: 210-225.

9. Ewing R, Schmid T, Killingsworth R, Zlot A, Raudenbush S. Relationship between urban sprawl and physical activity, obesity, and morbidity. Am J Health Prom 2003;18(1):47-57.

10. World Health Organization. Sedentary lifestyle: a global public health problem. Geneva: WHO; 2002.

11. World Health Organization. The world health report 2002: reducing risks, promoting healthy life. Geneva: WHO; 2002.
12. Colditz GA. Economic costs of obesity and inactivity. Med Sci Sports Exerc 1999;31(11 suppl):S663-667.

13. Pratt M, Macera C, Wang G. Direct medical costs associated with physical inactivity. Phys Sportsmed 2000;28(6):63-70.

14. Andersen LB, Schnohr P, Schroll M, Hein HO. All-cause mortality associated with physical activity during leisure time, work and cycling to work. Arch Intern Med 2000;160:1621-1628.

15. United States Department of Health and Human Services. Physical activity and health: a report of the Surgeon General. Atlanta, Georgia: Department of Health and Human Services, Centers for Disease Control and Prevention, National
Center for Chronic Disease Prevention and Health Promotion, The Presidents' Council on Physical Fitness and Sports; 1996.

16. Dunn AL, Marcus BH, Kampert JB, Garcia ME, Kohl HB 3rd, Blair SN. Comparison of lifestyle and structured interventions to increase physical activity and cardiorespiratory fitness: a randomized trial. JAMA 1999;281:327-334.

17. World Bank. Getting the best of cities. In: World development report 2003: sustainable development in a dynamic world: transforming institutions, growth, and quality of life. Washington, D.C.; World Bank; 2003. Pp. 107-126.

\section{Convocatoria a la propuesta de estudios para el Premio Fred L. Soper 2004}

La Fundación Panamericana de la Salud y la Educación (PAHEF) solicita propuestas para el Premio Fred L. Soper, otorgado anualmente a un artículo de investigación que aporte conocimientos novedosos sobre temas de salud pública de interés para América Latina 0 el Caribe. Los estudios propuestos para el premio que se otorgará en 2004 deberán haber sido publicados en 2003 en revistas científicas que figuren en el Index Medicus 0 en las publicaciones oficiales de la Organización Panamericana de la Salud (OPS), y sus autores deberán estar afiliados a instituciones docentes, de investigación o de servicios ubicadas en países de América Latina 0 el Caribe, incluidos los centros colaboradores de la OPS. Los estudios pueden ser experimentales o de observación y consistir en análisis de datos nuevos 0 en revisiones de datos primarios, pero interesan sobre todo los de naturaleza multidisciplinaria y los que versan sobre enfermedades infecciosas, que eran el campo de interés particular del Dr. Soper. Cualquiera puede proponer un trabajo como candidato al premio, incluso sus propios autores.

El premio, que consiste en un diploma y un premio en efectivo de US $\$ 2.500$, se otorga en honor del Dr. Fred L. Soper, Director de la OPS de 1947 a 1958 y uno de los salubristas más destacados del siglo XX. PAHEF maneja el fondo dedicado al premio y mantiene una cuenta especial para donaciones voluntarias. Los finalistas son elegidos por el Comité del Premio, cuyos miembros son designados por la OPS y PAHEF. Todas las candidaturas deberán recibirse a más tardar el 15 de junio de 2004.

Dirección para el envío de las propuestas:

Comité de Selección Premio Fred L. Soper

Fundación Panamericana de la Salud y Educación

525 Twenty-third Street, N.W.

Washington, D.C. 20037, U.S.A.

Tel.: 202-974-3416

Fax: 202-974-3636

Correo electrónico: pahef@paho.org

Internet: http://www.paho.org/Spanish/PAHEF/soper.htm 